DOI: $10.1515 /$ pof-2016-0003

VOLUME 8, ISSUE 1, 2016

ISSN: $2036-5438$

\title{
Clarifying Limbo: Disentangling Indigenous Autonomy from the Mexican Constitutional Order
}

by

Ian Flannigan Sprague*

Perspectives on Federalism, Vol. 8, issue 1, 2016 


\begin{abstract}
In contrast to U.S. Federal Indian law, which has classified indigenous tribes as "domestic dependent nations" since the early $19^{\text {th }}$ century, Mexican law has only recently begun to define the political and territorial autonomy of indigenous groups. This paper contrasts the Mexican approach to this problem to that of the United States, first describing Mexico's 2001's constitutional reforms and their failure to clarify the nature of tribal sovereignty. It then analyzes recent court cases that protect tribal political and territorial autonomy by applying rights to consultation contained in the International Labor Organization's Indigenous and Tribal People's Convention 169 ("ILO 169") and the Mexican Constitution. It concludes by arguing that in spite of this effort by the courts, Mexican law still requires a comprehensive legislative or diplomatic resolution of the lack of clarity surrounding the political and territorial autonomy of its indigenous groups.
\end{abstract}

Key-words

Mexico, Native American, Indigenous, Federal Indian Law, Chéran, Zapatista, EZLN, Sovereignty, Federalism 


\section{Introduction}

Since it achieved independence from Spain, Mexico's relationship with its indigenous cultural origins has been somewhat paradoxical. As one Mexican academic described it, 'the construction of the national identity is ambivalent and contradictory: it exalts the precolonial past of its ethnic societies, but it rejects and negates their continuing force.' Sitton (2011: 99). As indigenous people in Mexico in recent years have demanded recognition of their cultural and political autonomy, this observation has never been more apt. Bárcenas (2008: 56-60). The direct descendants of the precolombian societies still exist today (by some measures, 13 million out of a total population of 120 million), and despite having been marginalized culturally, socially, and economically, many have continued to speak their languages and observe their customs and culture. León-Portilla (2011: 108). ${ }^{\mathrm{I}}$ Nevertheless, throughout its history, Mexico's constitutions and courts have ignored indigenous peoples' existence and failed to develop a legal doctrine that defines the level of sovereignty of indigenous tribes under Mexican law. ${ }^{\text {II }}$ León-Portilla (2011: 108). This lack of clarity stands in the way of indigenous groups' efforts to achieve some measure of political and territorial autonomy today, leaving them in "limbo."

In contrast, courts in the United States have engaged with indigenous tribes from an early date, interpreting treaties and defining the tribes' relationship to the federal-state hierarchy established by the U.S. Constitution of 1788. These early court cases, which established that indigenous tribes were "domestic dependent nations" with inherent, if limited, sovereignty, have proved crucial in the development of legal doctrines that preserve tribal self-government and territory in the U.S. to the present day.

Below, I discuss in greater depth U.S. courts' approach to clarifying the status of tribal sovereignty. Next, I provide a short background of Mexican indigenous law, and argue that in spite of a recent trend of Mexican federal courts protecting indigenous political and territorial autonomy, Mexican law still fails to clarify the position of indigenous groups within the legal order, leaving them vulnerable to exploitation by local authorities. While this vulnerability affects all aspects of indigenous life and sovereignty, I 
focus specifically on the way current law impairs tribal rights to self-government ("political autonomy") and to land and resources ("territorial autonomy").

Before beginning my analysis, I would like to present several reasons why this particular comparison between U.S. and Mexican law is important. First, the two nations are federalist, and thus confront the same conceptual challenge of defining how tribal sovereignty can fit within a system of sovereign states and a sovereign national government. Next, because the two countries are neighbors, many indigenous people that live in both nations are ethnically and culturally related. Indeed, there are even tribes like the Yaquis of Sonora and Arizona that have been bisected by the U.S.-Mexico border. Third, many of the millions of Mexican immigrants who have arrived in the U.S. in recent decades are indigenous. Fourth, this is an area of Mexican law that has developed considerably in recent years, calling for a comparative perspective on the recent changes. Finally, this topic is intimately related with economic marriage of the two nations under the North American Free Trade Agreement (NAFTA). The Zapatista rebellion of 1994, which led to many of the legal changes I discuss below, began on the very day that NAFTA took effect. Understanding how indigenous groups are treated in U.S. and Mexican law will help transnational policymakers, investors, and defenders of indigenous rights.

While the focus of this paper is primarily the recent developments in Mexican indigenous law, viewed through the lens of U.S. law, I do not mean to suggest that U.S. Indian law is ideal or fully realized. If any lesson is to be learned from the comparison, it is that indigenous people must always be watchful against usurpations of their autonomy and territory.

\section{U.S. Tribes: Domestic Dependent Nations}

"Vulnerable" and "in limbo" are apt ways to describe the state of tribal sovereignty in the United States since the ratification of the U.S. Constitution in 1788. Nevertheless, tribes have enjoyed some measure of legal certainty because U.S. courts have historically recognized their inherent, if limited, sovereignty and vindicated tribal rights contained in treaties. This approach has been echoed by federal legislation like the Indian Self Determination and Educational Assistance Act of 1975 and the scholarship of Felix Cohen, both of which emphasize the inherent sovereignty of tribes originating in their 
status as foreign entities that pre-existed the formation of the United States. 25. U.S.C. Sections 471 et. Seq.; Cohen (1945).

The first U.S. jurist to attempt to explain the place of native tribes in relation to the federal and state governments was Chief Justice of the U.S. Supreme Court John Marshall. In his trilogy of Indian law cases, Johnson v. McIntosh, Cherokee Nation v. Georgia, and Worcester v. Georgia, John Marshall established the basic legal definition of Indian tribes in the United States-as "domestic dependent nations," not accorded the status of foreign nations, but at the same time enjoying whatever inherent sovereignty the Federal Government did not explicitly take from them. Johnson v. McIntosh, 21 U.S. 543 (1823); Cherokee Nation v. Georgia, 30 U.S. 1 (1831), Worcester v. Georgia, 31 U.S. 515 (1832). This juridical innovation reflected the historical practice of treatymaking with the Indian tribes, which lasted until 1871 and presupposed the sovereignty of tribal counterparties. In Worcester, the court invalidated a Georgia law that purported to regulate the activities of the Cherokee tribe on their reservation. 31 U.S. 515. Chief Justice Marshall mined the language of treaties between the U.S. Government and tribes to support the following endorsement of tribal political and territorial sovereignty:

'The Cherokee nation, then, is a distinct community occupying its own territory, with boundaries accurately described, in which the laws of Georgia can have no force, and which the citizens of Georgia have no right to enter, but with the assent of the Cherokees themselves, or in conformity with treaties, and with acts of Congress.' 31 U.S. at 562 .

In addition to affirming the potency of the Cherokee tribe's sovereignty, Marshall here established its place within the Federalist system-potentially subject to the federal government, but not to the states.

In the years since Marshall, the doctrine of domestic dependent nations has persisted, and courts have continued to recognize the tribes' political and territorial sovereignty. In the 1896 case Talton v. Mayes 163 U.S. 376, the Supreme Court held that the U.S. Constitution's individual rights protections did not apply against tribal governments, because the tribe's prosecutorial power derived from inherent sovereignty that pre-existed the United States, while the Constitution only protected individuals against the Federal 
Government. Talton v. Mayes, 163 U.S. 376 (1896). With respect to land and resources, courts developed a canon construing treaties in favor of pre-existing tribal rights not expressly derogated in treaties. See United States v. Winans, 198 U.S. 371 (1905) (construing an 1855 treaty to protect the Yakima tribe's reservation fishing rights); Winters $v$. United States, 207 U.S. 564 (1908) (construing a treaty in favor of protecting tribal rights to irrigation water).

As the nation continued to industrialize and modernize throughout the $20^{\text {th }}$ Century, courts continued to conceive of tribes as domestic dependent nations, with pre-existing and independent political and territorial sovereignty. In the seminal 1959 case Williams $v$. Lee, the U.S. Supreme Court dismissed an Arizona state court judgment against several Navajo defendants who had failed to pay for goods from a store on the reservation that was operated by a non-Indian. Citing John Marshall extensively, Supreme Court Justice Black noted, 'originally the Indian tribes were separate nations within what is now the United States,' and strongly rejected the state court's attempt to exercise jurisdiction over a matter within the competence of tribal courts: 'absent governing Acts of Congress, the question has always been whether the state action infringed on the right of reservation Indians to make their own laws and be ruled by them.' Williams v. Lee, 358 U.S. 217, 269-71 (1959). Williams v. Lee signaled the seriousness with which the modern court viewed the doctrine of Indian sovereignty expounded by John Marshall, and ushered in a period of increased court protection of Indian self-government.

Similarly, in the 1978 case U.S. v. Wheeler, 435 U.S. 313 (1978), the U.S. Supreme Court upheld a federal indictment for statutory rape arising out of the same incident which had given rise to a previous Navajo tribal court conviction, holding there was no danger of double jeopardy. ${ }^{\text {III }}$ The Court based its judgment on the independent origin of tribal power:

'In sum, the power to punish offenses against tribal law committed by Tribe members, which was part of the Navajos' primeval sovereignty, has never been taken away from them, either explicitly or implicitly, and is attributable in no way to any delegation to them of federal authority. It follows that when the Navajo Tribe exercises this power, it does so as part of its retained sovereignty and not as an arm of the Federal Government.' U.S. v. Wheeler, 435 U.S. 313 at 398. 
U.S. states also benefit from this avoidance of the double jeopardy prohibition, reflecting the strength of tribal sovereignty as conceived by the court.

As a final point, it must be noted that U.S. law has also always included limitations on indigenous sovereignty, highlighting the fragility of tribal autonomy. Beginning with Marshall in Johnson v. McIntosh, the U.S. Supreme Court recognized that Indians had only limited title to the land they inhabited, and could not treat with foreign powers other than the United States. Later in the $19^{\text {th }}$ Century, the court in the cases U.S. v. Kagama, 118 U.S. 375 (1886), and Lone Wolf v. Hitchcock, 187 U.S. 553 (1903), developed the concept of the unchecked "plenary power" of Congress to legislate on Indian matters. This doctrine is reflected by the "reserved" nature of Indian sovereignty described above-as long as the U.S. Congress has not said otherwise, sovereignty is reserved to tribes. More recently, in the case Oliphant v. Suquamish Indian Tribe, 435 U.S. 191 (1978), the court added an additional limitation on indigenous sovereignty — tribes could not prosecute non-members for offenses committed on reservation grounds. In spite of these threatening developments for the future of Indian self-government, the reality as it stands today is that tribal selfgovernment is alive and well within clearly demarcated reservations throughout the United States.

\section{Limbo Persists: A Brief Review of Mexican Indigenous Law}

In contrast, Mexican law has only recently begun to grapple with the status of its indigenous tribes. Before a 1992 constitutional amendment that explicitly recognized the "pluricultural" nature of the Mexican Republic, the Mexican Constitution of 1917 (as well as those previous to it) lacked any clear references to indigenous people at all. Vargas (1994: 42-43). In addition, there is no general historical practice of treatymaking with indigenous tribes in Mexico. IV This is all especially surprising because Mexico's indigenous population is far greater in absolute and proportional terms than that of the United States, comprising at least $10 \%$ of a total population of about 120 million ( $\approx 13$ million). ${ }^{\mathrm{V}}$ LeónPortilla (2011). Further, the revolution that produced the current 1917 Mexican Constitution was propelled by indigenous people seeking the restoration of their patrimonial lands and redress against the tyrannies of local non-Indian capitalists and landowners. León-Portilla (2011). One need look only to the example of the pure-blooded 
Zapotec Benito Juarez, considered one of Mexico's greatest jurists and reformers, to observe the influence of indigenous people on the development of Mexican legal institutions. $^{\text {VI }}$

However, after the 1992 Amendment and the Zapatista Rebellion of January 1, 1994, the Mexican government has begun to address the political autonomy of indigenous tribes in Mexico. The most important example of this are the historic San Andrés Accords of 1996, the fruit of negotiations between the Mexican government and indigenous groups led by the Zapatista National Liberation Army (EZLN) after their 1994 uprising. While the Accords could have set the precedent for a new practice of treatymaking between tribes and the government, they were not recognized as a treaty obligation after their signing in 1996. Zamora et al. (2004). Instead, the Mexican government responded to them by passing the constitutional amendments of August 14, 2001, which included unilateral modifications to the Accords. On their face, the Amendments of 2001 recognize some forms of tribal autonomy, but in reality they are significantly short of what was bargained for between the EZLN and the Mexican Government in the 1990s, and have been rejected as ineffective by indigenous law scholars in Mexico. Sitton (2011); Bárcenas (2008); Corres (2011). Below, I will discuss how the 2001 amendments failed to implement the San Andrés Accords with respect to clarifying the boundaries of tribal political and territorial autonomy.

3.1. The 2001 Amendments and their failure to establish indigenous political autonomy

In spite of the 2001 amendments' apparent endorsement of indigenous autonomy, they are limited by a lack of clarity regarding the place of indigenous groups within Mexican constitutional structure. This deficiency differentiates Mexican from U.S. law on the subject, which has we have discussed above has a long tradition of refining the nature of tribes as "domestic dependent nations." In Mexico, while the San Andrés Accords granted full autonomy to indigenous groups on a scale from the smallest settlements to region-wide agglomerations of settlements, the 2001 Amendments delegate the definition and recognition of autonomy to the states, and only explicitly grant legal status to indigenous comunidades, which are small-scale settlements. De la Rosa (2014: 31). ${ }^{\text {VII }}$ This is especially insufficient because, as in the United States, Mexican state governments have traditionally 
been the most aggressive expropriators of tribal lands and oppressors of indigenous people. Bárcenas (2008). ${ }^{\text {VIII }}$ Unsurprisingly, the response to the constitutional amendments by the states was tepid: as of 2011, only 21 of 32 states' constitutions mentioned indigenous people in any way. Of those, half are obsolete because they predate the 2001 constitutional amendments. In addition, by 2011 only 11 states had conformed their constitutions to the 2001 constitutional amendments, and 9 of those only passed the minimum that would conform to the constitutional mandates. Corres (2011).

Further, the legal status granted to comunidades fails to meet the terms of the Accords or clarify their nature. Instead of amending the constitutional provisions establishing the structure of local and state government to include indigenous communities as full-fledged local governments, the 2001 amendments only establish them as entities of interés publico, an undefined term. Díaz (2002: 155); Diaz-Polanco (2009); De la Rosa (2014:31); Stavenhagen (2014: 40). According to some interpretations by Mexican law scholars, these entities are comparable to political parties and other voluntary associations. Díaz (2002: 155); DiazPolanco (2009); De la Rosa (2014:31); Stavenhagen (2014: 40). The 2001 amendments also fail to carry out the Accords' provision calling for the redistricting of municipal and submunicipal boundaries within states in order to improve the political participation of indigenous people in local, state, and federal representative bodies. De la Rosa (2014). The lines demarcated by these entities not only ignore indigenous communities, they slice them up into political oblivion. After the creation of the federal system in 1821,

'Not a single state, excepting Tlaxcala, corresponded to the indigenous peoples that lived within them, often splitting them into several states, and internally, splitting them among local government entities. This prevented the political unity of indigenous peoples and avoided their political or economic strengthening.' Sitton (2011: 99).

The result of these weaknesses is a reform that grants very little in the way of political autonomy to indigenous tribes in México.

This perception is reinforced by the language of the 2001 amendments themselves, which condition their grant of free determination to indigenous groups on the requirement that it be exercised 'in a constitutional frame of autonomy that assures national unity.' Constitución Política de los Estados Unidos Mexicanos, Art. 2. Indeed, the title of Article 
II (pertaining to Indigenous Mexicans) is 'The Mexican Nation is unified and indivisible.' José Ramón Cossío Díaz, a Mexican Supreme Court Justice, explains the circularity of this simultaneous grant and limitation: 'free determination can only be exercised under the terms and conditions of the juridical order, while the juridical order itself grants free determination.’ Díaz (2002: 154). Justice Cossío Díaz resolves this quandary by suggesting that "free determination" really means only those powers of self-government explicitly provided in Article II. Díaz (2002: 154). As a result, Mexico’s 2001 amendments grant autonomy in a context that is highly limited by obligations to conform to the preexisting majority constitutional structure. This is in striking contrast to the U.S. approach, illustrated by the case U.S. $v$. Wheeler, where the Supreme Court has conceived of indigenous autonomy as inherent and reserved, because before the coming of the Europeans, the tribes were self-governing sovereign political communities.' 435 U.S. 313, at 322-3.

In sum, the lack of clarity with respect to the nature of indigenous groups' political autonomy prevents the 2001 amendments from meeting the terms of the San Andrés Accords or helping eliminate tribal "limbo." As we have seen in the U.S., the clear legal and territorial demarcation of Indian Tribes have been essential to the protection of tribal autonomy in court. As long as the nature of Mexican tribal sovereignty remains undefined, indigenous rights to self-govern will be extremely difficult to vindicate.

\subsection{The 2001 Amendments and their failure to sufficiently protect indigenous} territorial autonomy

The 2001 amendments' lack of clarity also obstructs indigenous efforts to protect territorial integrity. The special rights to land and resources granted to indigenous groups by the 2001 amendments are unclear and limited by entanglement with the majority constitutional order. Like in the United States, tribal control over land and resources has been a key point of contention in Mexico since the first Europeans arrived. Unlike the U.S., however, indigenous groups in Mexico lack treaties that clearly define the extent of their territories and territorial rights. The protection of indigenous-owned lands and the restoration of wrongly taken lands were important topics in the San Andrés negotiations, especially because of the EZLN's locus in the state of Chiapas and that state's notorious record of illegal expropriation. Vargas (1994); León Portilla (2011); Bárcenas (2008). ${ }^{\text {IX }}$ As 
foreign investment in Mexico has increased in recent years, the problem of land insecurity has only worsened-from 1993 to 2012, the government granted 43,675 mining concessions, which represent a surface area covering nearly half of Mexico. Veloz (2014: 24). In addition, between 2000 and 2010 gold mines in Mexico produced 420 tons of gold, more than double the amount produced in three centuries of Spanish colonial rule. Veloz (2014: 24).

The absence of clear territorial rights is particularly obvious in 2001's amendments, which allow for the "preferential use" by indigenous people of natural resources in the areas they inhabit, subject to the rights of third parties, individual property owners within their communities, the forms of property and tenancy recognized by the Constitution, and excepting "strategic areas," also defined by the constitution (but beyond the scope of this paper). From the start, this grant did not meet the requirement of the Accords, which called for access and use rights to the "lands and territories" of the tribes. De la Rosa (2014: 30). "Lands and territories" was understood to include a sphere much greater than lands where indigenous people live and practice agriculture, encompassing sites of religious and cultural interest, but in the 2001 amendments, the area is limited to that which is inhabited by indigenous people. De la Rosa (2014: 30). Beyond the concerns over the highly limited nature of this grant of rights, Professor Francisco Bárcenas points out that the amendments diverge from the Accords in that they grant access to the use of resources in the areas where they live, rather than to actual ownership of the land or repatriation of expropriated territories. Bárcenas (2008: 100). While in the U.S., tribal property rights are also restricted, the tribes at least have the advantage of treaties that demarcate the extent of the lands they control and grant them possession and many other reserved rights. ${ }^{\mathrm{x}}$ In contrast, the 2001 amendments' 'grant' of rights is so adulterated by the conditions of prevailing constitutional order as to be null.

\section{2011- present: The Mexican Federal Courts and the Right to Consultation}

Mexican jurisprudence in the area of indigenous rights has historically been rigid and formalistic: for example, in response to 300 legal challenges to the validity of 2001's constitutional amendments, the Mexican Supreme Court refused to hear the cases on 
separation of powers grounds (as well as a special power afforded Congress as the reformer of the constitution). Bárcenas (2008: 102-103). Since 2011's constitutional reforms to the Mexican court system, which elevated international treaty obligations in the area of human rights to constitutional guarantees, the federal courts have turned away from formalism and begun to expand upon the limited protections of indigenous political and territorial autonomy granted by the 2001 amendments. ${ }^{\text {XI }}$ This protection has been accomplished most successfully through the vindication of indigenous peoples' rights to consultation, contained in Article 6 of the International Labor Organization's Indigenous and Tribal People's Convention 169 ("ILO 169") and Article 2 of the Mexican Constitution. Article 6 (a) of ILO 169, signed by Mexico in 1990, requires governments to 'consult the peoples concerned, through appropriate procedures and in particular through their representative institutions, whenever consideration is being given to legislative or administrative measures which may affect them directly.' Below, I will discuss several recent cases where indigenous tribes defended their political autonomy and access to natural resources by successfully asking the Mexican Supreme Court to vindicate this right.

\subsection{Cherán—self-government by uses and customs through consultation}

The most striking example of the use of consultation rights to protect political autonomy is the case of Cherán, Michoacán, a community of some 18,000 Purépecha people. La Jornada 20 April 2015. In a series of recent litigations in federal courts against a hostile state government, the Purépechas successfully established Cherán as an indigenous municipality governed by their own uses and customs. A silvicultural community that relies on the maintenance and careful exploitation of forests, the Purépecha in Cherán suffered for years from illegal logging and organized crime that was permitted and encouraged by local municipal authorities. Arévalo and Andrade (2013); La Jornada 20 April 2015; El Universal 29 May 2014. In 2011, a group of residents set up barricades in their town, directly confronting illegal loggers and driving corrupt local officials out. Arévalo and Andrade (2013); La Jornada 20 April 2015; El Universal 29 May 2014. The next local election cycle, the people of Cherán attempted to elect their local leaders according to their tribal customs, and petitioned the regional electoral authority to be allowed to do so. Arévalo and Andrade (2013); La Jornada 20 April 2015; El Universal 29 May 2014. After their request was rejected by the regional agency, they sued in the Federal Election Court, and won a 
judgment ordering the regional agency to hold a consultation process to verify that the community did indeed want to elect local leaders according to their customs. Arévalo and Andrade (2013); La Jornada 20 April 2015; El Universal 29 May 2014. The process resulted in a resounding 'yes' for the customary election. Arévalo and Andrade (2013); La Jornada 20 April 2015; El Universal 29 May 2014. Shortly after this favorable ruling in 2012, the legislature of Michoacán enacted a state constitutional reform directly disallowing Cherán's freedom to elect its own leaders according to tribal customs. Mosso (2014). This resulted in further litigation, culminating in a Supreme Court judgment in May 2014 invalidating the state constitutional reform as it applied to Cherán because of the state legislature's lack of consultation with the town. Controversia Constitucional 32/2012; Aranda (2014). ${ }^{\text {XII }}$ This ruling was especially notable for two reasons: first, because it was the first ruling to recognize that indigenous communities have standing to litigate their constitutional rights against states. Secondly, because the ruling affirmed the parity between "normal" municipalities, structured as direct democracies according to Article 115 of the Mexican constitution, and indigenous municipalities, governed by "customs and uses." Dávila (2014); Aranda and Martinez (2011). By taking action to protect their right to consultation, the people of Cherán successfully protected their freedom to self-govern.

\subsection{The Yaquis and the Mayas-territorial autonomy through consultation}

In the 2013 Supreme Court case "Amparo en Revisión 631/2012," the court granted constitutional protection to the Yaqui Tribe's rights to $50 \%$ of the water contained in the Angostura Dam in the state of Sonora. Amparo en Revisión, 613/2012; La Red Internacional. While the state had already constructed and begun to operate the Aqueducto de la Independencia taking water from the Angostura reservoir to the city of Hermosillo, the court ruled that the construction of the reservoir was illegal. It invalidated the aqueduct's operating permits because of a failure to adequately consult with the tribe, which depended on the reservoir for irrigation. Amparo en Revisión, 613/2012; La Red Internacional. Importantly, the basis of the tribe's claim to $50 \%$ of the water in the dam was an agreement with the Mexican government, signed in 1937, and followed by a presidential decree in 1940. Vázquez (2012). In this respect, the Yaqui were the exception: a Mexican indigenous group that could rely upon a written agreement similar to those relied upon by U.S. tribes to protect territorial rights. See Winters v. United States, 207 U.S. 
564 (1908). In another recent case from the fall of 2015, the Mexican Supreme Court invalidated licenses issued by a federal agency for the planting of genetically modified soy in the Yucatán, based on complaints by Maya peoples. Notimex (2015). The court similarly relied on the agency's failure to properly consult with the tribes before issuing the license that would profoundly affect their agricultural and honey-harvesting practices. Notimex (2015).

\subsection{The limitations of courts in vindicating political and territorial autonomy}

The successful court battles described above sadly reveal the limitations of the court's role in protecting indigenous political and territorial sovereignty in today's Mexico. In the case of the Yaquis of Sonora, the implementation of court's original judgment has been delayed and ignored by local authorities and the litigation continues to this day. Román (2015); La Red Internacional. In the case of Cherán, while the town has successfully governed itself since 2011, in 2015 the state legislature passed a law that again restricted their local autonomy, clearly violating the Supreme Court Judgment of 2014. ${ }^{\text {IIII }}$ Moreover, the application of the 2011 reforms by courts has been irregular-in Baja California, the Cucapá tribe's constitutional challenge to environmental fishing limits that were passed without consultation was rejected by a federal district judge in 2014, in spite of widespread agreement among experts that their rights had been violated. Díaz (2014); Navarro-Smith et al. (2014).

Unsurprisingly, in the face of courts' limited potency, intransigent local authorities, and growing threats from organized crime, indigenous groups have increasingly turned to the practice of de facto autonomy. A longstanding example of this has been the EZLN's regional autonomous governments in the mountainous jungles of Chiapas. Diaz-Polanco (2009: 67). More recently, the rise of cartel violence and local corruption in southern Mexico has spurred additional attempts at de facto autonomy. ${ }^{\text {XIV }}$ In Guerrero, rural indigenous militias have been formed to protect communities from narcotraffickers and corrupt government officials. Agren (2015); Stavenhagen (2014: 46). 


\section{Conclusion-comprehensive solutions needed}

After hundreds of years without explicit legal recognition, in recent years indigenous people can finally see themselves in the text of the Mexican Constitution. By clarifying the political and territorial boundaries of indigenous tribal sovereignty, indigenous and nonindigenous people alike can further benefit from some measure of legal certainty.

While the recent rulings in Mexican courts with respect to consultation rights are admirable, the judicial branch is limited by the laws and treaties it implements and the constrained remedies that adjudication can afford. Even in the U.S., where courts have recognized inherent tribal sovereignty for nearly 200 years, they did not labor alone. Tribal sovereignty has been supported by executive and legislative action throughout the years, in the form of treaty negotiation and ratification, and the passage of laws like as the Indian Reorganization Act of 1934 and the Indian Self Determination and Educational Assistance Act of 1975. Indeed, Marshall's most resounding endorsement of tribal sovereignty and territory, his opinion in the case Worcester v. Georgia, did nothing to prevent the forcible removal of Cherokees from their land that was occurring at the time.

Viewing the 2001 amendments and recent Mexican Supreme Court rulings through the lens of U.S. Federal Indian Law, it is clear that indigenous people in Mexico suffer from a lack of clarity with respect to their tribal political and territorial autonomy. In addition to the court participation of the last few years, there is a great need for a complete resolution of tribal "limbo" through legislation or constitutional reforms recognizing clear territorial boundaries and well-defined political autonomy. A clear answer, accepted by all branches of government and the states, is essential. As always, the San Andrés Accords stand as a reminder of an agreement that apparently satisfied all parties at the bargaining table-it would never be too late to re-adopt the Accords as a treaty, giving it constitutional status and assuring its implementation.

\footnotetext{
* Third year law student at Columbia Law School. This paper was written at Columbia and the Instituto Tecnológico Autonómico de México (ITAM) in Mexico City. I would like to thank Professor Steven McSloy of Columbia, and Professors Francisca María Pou Giménez and Luis Raigosa Sotelo of ITAM for their assistance on this project.

I Under some U.S. tribes' blood-quantum requirements, Mexican "mestizos" would qualify, rendering the vast majority of the Mexican population as "indigenous" as many U.S. tribal members. See Adoptive Couple v. Baby Girl, 133 S.Ct. 2552, 2556 (2013).

II While the word "tribes" has a different meaning in Mexico, where it refers primarily to northern indigenous groups, for uniformity's sake, I use it throughout this paper in the U.S. sense of the word to describe
} 
culturally distinct and self-governing (in fact, if not in law) groups of indigenous people.

III "Double Jeopardy," is a defense that can be used to prevent the trial of a defendant for the same offense for which he/she was already acquitted or convicted.

IV An exception to this rule is the Yaqui tribe of Sonora, whose history of successful violent resistance against the Mexican State has allowed it to benefit from treaties, agreements and presidential decrees giving it a sphere of de jure autonomy. As we will see below, this history has helped the tribe to vindicate water rights in court in recent years. SV Vázquez (2012).

v According to the 2010 U.S. Census, there are 5.2 million American Indians and Native Alaskans in the U.S., comprising $1.7 \%$ of the total population.

VI The case of Benito Juarez also serves to illustrate the paradox of Mexican-Indigenous relations-the process of Liberal constitutional reform in which he participated denied Indian tribes any collective rights and greatly aided the expropriation of lands held by indigenous people. León-Portilla (2011).

VII In addition to its limited scope, this reform doesn't appear to add much-comunidades are already recognized as units of collective property ownership under the Constitution's provisions on Agrarian Reform. They do not have an explicit connection to indigenous Mexicans, however. Constitución Política de los Estados Unidos Mexicanos, Art. 27.

VIII Nevertheless, it must be noted that given the cultural and geographic heterogeneity of Mexico, there is also a good-faith rationale for delegation of this matter to the states.

IX 'Chiapas is Mexico's poorest state for Indians, but a paradise for caciques.' Vargas (1994: n. 8). Caciques are local political bosses, often large landowners.

$\mathrm{x}$ Around 56 million acres of U.S. tribal land is held in trust, for the benefit of tribes, by the Federal government. This means there are restrictions on the ability of indigenous people to sell or lease the land, but they are presumed to have the "full beneficial ownership of the land, minerals, timber, and other associated property interests. Fletcher (2011: 20-21, 248); United States v. Shoshone Tribe of Indians, 304 U.S. 111 (1938). This limited "indian title" can be traced to Johnson v. McIntosh, 21 U.S. 543 (1823).

XI In other words, actions against the government for violations of rights can now claim violations to human rights ensured by international treaties signed by Mexico. 'Que hace el SCJN?'

XII Without getting into the weeds of Mexican constitutional procedure, the ruling was limited in its effect to Cherán-it is rare for courts to strike laws facially in Mexico.

XIII After the threat of another lawsuit, the legislature finally corrected the law. PM Vázquez, (2015).

XIV The most extreme example of this is the disappearance of 43 students from the Normal School of Ayotzinapa, Guerrero, the majority of whom were indigenous and training to be teachers in indigenous communities. "You have to be poor, from the working or agricultural class, and usually indigenous to become an Ayotzi ...... The teachers who graduate from the school, who usually go out into isolated and impoverished rural communities to teach ..." Goldman, (2015).

\section{References}

- $\quad$ Agren David, 2015, 'Mexican state sees surge in violence', The Guardian, 17 November 2015.

- Aranda Jesús, 2014, 'Invalida SCJN reformas a constitución de Michoacán en derechos indígenas,' La Jornada, 29 May 2014.

- Aranda Jesús and Elorriaga Ernesto, 2011, 'Autoridades indígenas podrán impugnar leyes ante la Corte,' La Jornada, 28 May 2011.

- Arévalo Erika and Andrade Iran, 2013, 'México: el Caso Cherán,' in Schilling-Vacaflor ArmutFlemmer Riccarda (eds), El derecho a la consulta previa: Normas juridical, prácticas y conflictos en América Latina, Deutsche Gesellschaft für Internationale Zusamennarbeit, 42, https://giga.hamburg/sites/default/files/md pdf/1303 destradi konferenzbericht es.pdf (https://perma.cc/7WUA-MZQ3).

- Bárcenas Francisco López, 2008, Autonomía y Derechos Indígenas en Mexico, UNAM, Ciudad de México.

- Cohen Felix, 1945, The Handbook of Federal Indian Law, (1st edn) US Government Printing Office, Washington, D.C. 
- Corres Jaime Bailón, 2011, 'Adecuación de los marcos jurídicos a la reforma indígena de 2001,' in Espejel José Gabriel Baeza, Guerrero María Gabriela Gómez, Silva Noemi (eds), Pueblos Indígenas: Debates y Perspectivas, UNAM, Ciudad de México.

- Cossío Díaz José Ramón, 2002, Problemas del derecho indígena en México, Comisión Nacional de los Derechos Humanos, Ciudad de México.

- Dávila René, 2014, 'Cherán: una memoría recobrada para los derechos indígenas,' Journalmex Periodistas de México, 5 June 2014.

- De la Rosa Sebastian, 2014, 'Palabras del diputado Sebastian de la Rosa en el foro de derechos indigenas y armonizacion legislative,' in Moguel Julio (ed), Derechos Indigenas y Armonizacion Legislativa, Juan Pablos Editor, Ciudad de México, 29-33.

- Díaz Gloria Leticia, 2014, 'La Sagarpa prohíbe pescar a indígenas del Golfo de California,' El Proceso, 9 April 2014.

- Diaz-Polanco Hector, 2009, La Diversidad Cultural y La Autonomia en Mexico, Nostra Ediciones, Ciudad de México.

- $\quad$ El Universal, 29 May 2014, 'Cherán y Poder.'

- $\quad$ Fletcher Matthew L.M., 2011, Cases and Materials on Federal Indian Law, 6th ed., Thomson/West, St. Paul, Minnesota.

- Goldman Francisco, 2015, 'The Missing Forty-Three: The Government's Case Collapses' in The New Yorker, 8 June 2015.

- La Jornada, 20 April 2015, 'Cumple Cherán 4 años de autogobierno, sin partidos.'

- La Red Internacional para los Derechos Económicos, Sociales, y Culturales, 'Amparo No. 631/2012 (Acueducto Independencia),' https://www.escr-net.org/es/node/365316 (https://perma.cc/TNR8-HFRN).

- León-Portilla Miguel, 2011, Independencia, Reforma, Revolución, y los indios qué?, UNAM, Ciudad de México.

- $\quad$ Mosso Rubén, 2014, 'En la corte, Cherán le gana al gobierno de Michoacán,’ El Milenio, 27 May 2014.

- Notimex, 2015, 'SCJN da revés a Monsanto sobre soya transgénica,' El Economista, 4 November 2015.

- 'Que hace el SCJN?', Mexican Supreme Court Website, https://www.scjn.gob.mx/conocelacorte/Paginas/atribucionesSCJN.aspx $\quad$ https://perma.cc/X5NWWLJA).

- Román José Antonio, 2015, 'Gana tribu Nuevo amparo contra Acueducto Independencia,' La Jornada, 18 May 2015.

- Sitton Salomon Nahmad, 2011, 'La Pluralidad étnica y la nación mexicana,' in Espejel José Gabriel Baeza, Guerrero María Gabriela Gómez, Silva Noemi (eds), Pueblos Indígenas: Debates y Perspectivas, UNAM, Ciudad de México, 81-104.

- Smith Alejandro Navarro, Espinosa Yacotzin Bravo, Lopez-Sagástegui Catalina, 2014, 'Derechos colectivos y consulta previa: territorio cucapá y recursos pesqueros en Baja California, Mexico,' Revista Colombiana de Sociología, XXXVII(2): 43-64.

- Stavenhagen Rodolfo, 2014, 'La nación ante el reto de los derechos indígenas,' in Moguel Julio (ed), Derechos Indigenas y Armonizacion Legislativa, Juan Pablos Editor, Ciudad de México, 35-46.

- Vargas Jorge A., 1994, 'NAFTA, The Chiapas Rebellion, and the Emergence of Mexican Ethnic Law,' California Western International Law Journal, XXV(1): 1-79.

- Vázquez Patricia Monreal, 2015, 'Ante amago de Cherán, corrige Congreso Ley de Mecanismos de Participación,' El Cambio de Michoacán, 13 September 2015.

- Vázquez Saúl Vicente, 2012, 'El caso del pueblo de la Tribu Yaqui, Sonora, Mexico’ in UN OHCHR Seminar on treaties, agreements, and other constructive arrangements, Geneva, July 2012.

- Veloz Jaime Martínez, 2014, 'Intervención de JM Veloz, comisionado para el Diálogo con los Pueblos Indígenas en México,' in Moguel Julio (ed), Derechos Indigenas y Armonizacion Legislativa, Juan Pablos Editor, Ciudad de México, 21-27.

- Zamora Stephen et al., 2004, Mexican Law, Oxford University Press, Oxford. 